\title{
Fibrella aestuarina gen. nov., sp. nov., a filamentous bacterium of the family Cytophagaceae isolated from a tidal flat, and emended description of the genus Rudanella Weon et al. 2008
}

Correspondence Homayoun C. Bagheri bagheri@ieu.uzh.ch

\author{
Manuela Filippini, ${ }^{1}$ Miroslav Svercel, ${ }^{1}$ Endre Laczko, ${ }^{2}$ Andres Kaech, ${ }^{3}$ \\ Urs Ziegler ${ }^{3}$ and Homayoun C. Bagheri ${ }^{1}$ \\ ${ }^{1}$ Institute of Evolutionary Biology and Environmental Studies, University of Zurich, \\ Winterthurerstrasse 190, 8057 Zurich, Switzerland \\ ${ }^{2}$ Functional Genomics Center Zurich, Winterthurerstrasse 190, 8057 Zurich, Switzerland \\ ${ }^{3}$ Center for Microscopy and Image Analysis, University of Zurich, Winterthurerstrasse 190, 8057 \\ Zurich, Switzerland
}

\begin{abstract}
A Gram-staining-negative, pink bacterium, designated strain BUZ $2^{\top}$, was isolated from coastal mud from the North Sea (Fedderwardersiel, Germany). Cells were rod-shaped and able to form multicellular filaments. Growth after 7 days was observed at $10-40{ }^{\circ} \mathrm{C}$, at $\mathrm{pH} 6-8$ and with $0-0.5 \% \mathrm{NaCl}$. The phylogenetic tree based on $16 \mathrm{~S}$ rRNA gene sequences indicated that strain BUZ $2^{\top}$ is a member of the family Cytophagaceae, its closest neighbours being Rudanella lutea $5715 \mathrm{~S}-11^{\top}$, Spirosoma linguale LMG $10896^{\top}$ and Spirosoma panaciterrae Gsoil $1519^{\top}(87.8$, 86.4 and $86.1 \%$ sequence similarity, respectively). The major fatty acids were summed feature 3 (comprising $\mathrm{C}_{16: 1} \omega 7 c$ and/or iso- $\left.\mathrm{C}_{15: 0} 2-\mathrm{OH}\right), \mathrm{C}_{16: 1} \omega 5 c$ and iso- $\mathrm{C}_{15: 0}$. The predominant respiratory quinone was $\mathrm{MK}-7$ and the major polar lipids were phosphatidylethanolamine and several unidentified aminophospholipids. The DNA G+C content was $56.5 \mathrm{~mol} \%$. On the basis of this polyphasic study, we propose that strain BUZ $2^{\top}$ represents a novel genus and species, for which the name Fibrella aestuarina gen. nov., sp. nov. is proposed. The type strain of Fibrella aestuarina is BUZ $2^{\top}$ (=DSM $22563^{\top}=$ CCUG $58136^{\top}$ ). An emended description of the genus Rudanella is also proposed.
\end{abstract}

The family Cytophagaceae (Ludwig et al., 2008) constitutes a phylogenetically diverse group within the phylum Bacteroidetes, comprising Spirosoma (Baik et al., 2007; Finster et al., 2009; Ten et al., 2009), Runella (Larkin \& Williams, 1978), Flectobacillus (Larkin et al., 1977), Larkinella (Vancanneyt et al., 2006; Kulichevskaya et al., 2009) and Rudanella (Weon et al., 2008) among other genera.

Strain BUZ $2^{\mathrm{T}}$ was isolated from a mud sample from tidal flats in Fedderwardersiel $\left(53^{\circ} 35^{\prime} 59^{\prime \prime} \mathrm{N} 8^{\circ} 21^{\prime} 23^{\prime \prime} \mathrm{E}\right.$, elevation $0 \mathrm{~m}$ ), on the North Sea coast of Germany. This strain was isolated using a selective nutrient agar containing kanamycin $\left(50 \mu \mathrm{g} \mathrm{ml}^{-1}\right)$, developed by Flint (1985) for the isolation and enumeration of Flavobacterium strains. Colonies were selected according to their colour. The strain

The GenBank/EMBL/DDBJ accession number for the 16S rRNA gene sequence of strain BUZ $2^{\top}$ is GQ141052.

Two supplementary figures are available with the online version of this paper. was cultivated in liquid Spirosoma medium (SM; DSMZ medium 7) and R2A broth (Reasoner \& Geldreich, 1985) and preserved as a glycerol suspension (1:1 mixture of glycerol and bacterial culture) at $-80{ }^{\circ} \mathrm{C}$.

Bacterial genomic DNA was extracted using the protocol described in Svercel et al. (2009). The 16S rRNA gene was amplified by PCR using the universal bacterial primers $27 \mathrm{~F}$ and $1525 \mathrm{R}$ in a Techne TC 512 thermal cycler (Barloworld Scientific). Sequencing was performed both in house (ABI 3730 Sequencer) and at an external facility (Microsynth AG, Balgach, Switzerland). Sequences were assembled and edited manually using the Geneious Pro 3.6.2 software. Phylogenetic analysis was performed with the software package MEGA version 4.1 (Kumar et al., 2001) following a multiple alignment of data with CLUSTAL_x2 (Thompson et al., 1997). Phylogenetic trees were constructed by using the neighbour-joining, minimal evolution, maximumparsimony and maximum-likelihood algorithms. Evolutionary distances were computed using the Kimura-2 model and the maximum composite likelihood method. 
Maximum-likelihood analysis was performed using Garli (Zwickl, 2006). These analyses were performed using 1000 bootstrap resamplings.

According to BLAST results based on a $1319 \mathrm{bp}$ fragment of the 16S rRNA gene, strain BUZ $2^{\mathrm{T}}$ is a member of the family Cytophagaceae. It shares the highest 16S rRNA gene sequence similarity with Rudanella lutea $5715 \mathrm{~S}-11^{\mathrm{T}}$ (87.9\%), Spirosoma linguale LMG $10896^{\mathrm{T}}(86.4 \%)$ and Spirosoma panaciterrae Gsoil $1519^{\mathrm{T}}$ (86.1\%). These values are significantly lower than the threshold level of $95 \%$ that is generally used to delineate a potential new genus (Ludwig et al., 1998). Rudanella lutea DSM $19387^{\mathrm{T}}$ and Spirosoma linguale DSM $74^{\mathrm{T}}$ were selected as reference strains and studied in parallel to the new isolate in all phenotypic tests. In the neighbour-joining tree based on 16S rRNA gene sequences, strain BUZ $2^{\mathrm{T}}$ formed a cluster with $R$. lutea $5715 \mathrm{~S}-11^{\mathrm{T}}$ with high bootstrap support (Fig. 1 ), in agreement with the other tree-calculating methods employed (not shown).

The Gram reaction was determined using the $\mathrm{KOH}$ test as described by Tindall et al. (2007). Bacterial cell morphology and gliding motility (Bernardet et al., 2002) were observed under a light microscope (Olympus BX-51) from liquid cultures grown in SM for 1 day. For transmission (Philips CM100; FEI) and scanning (Supra 50 VP; Zeiss) electron microscopy, strain BUZ $2^{\mathrm{T}}$ was grown for 4 days in $\mathrm{SM}$ broth at $30^{\circ} \mathrm{C}$. Cells for transmission electron microscopy were high-pressure frozen (EMPact2; Leica Microsystems) and freeze-substituted with anhydrous acetone with $2 \% \mathrm{OsO}_{4}$ (EMAFS2; Leica) before embedding in Epon (Sigma). For scanning electron microscopy, cells were chemically fixed with $2.5 \%$ glutaraldehyde in PBS and post-fixed with $2 \% \mathrm{OsO}_{4}$, dehydrated with a graded ethanol series, critical-point dried and coated with $5 \mathrm{~nm}$ platinum. The presence of flagella was also assessed by transmission electron microscopy after negative staining with $2 \%$ aqueous phosphotungstic acid.

Physiological and biochemical tests were performed at $30{ }^{\circ} \mathrm{C}$ unless otherwise indicated. Catalase activity was determined by adding a drop of $3 \% \mathrm{H}_{2} \mathrm{O}_{2}$ to colonies. Oxidase activity was assessed using the bioMérieux kit according to the manufacturer's protocol. Flexirubin-type pigments were detected based on a colour shift after exposure to a $20 \%(\mathrm{w} / \mathrm{v}) \mathrm{KOH}$ solution (Reichenbach, 1992).

Pigments were extracted with $99 \%$ ethanol according to Gosink et al. (1998). The absorption spectrum between 350 and $800 \mathrm{~nm}$ was recorded with a spectrophotometer (SpectraMax 384 Plus; Molecular Devices) after incubation for $10 \mathrm{~min}$ in the dark.

Growth was tested in R2A, SM, nutrient broth (NB; Becton Dickinson), $0.2 \%$ peptone water and $0.5 \%$ yeast water and on trypticase soy agar (TSA; Becton Dickinson), yeast extract tryptone agar (YT agar; Becton Dickinson), blood agar and MacConkey agar. Since strain BUZ $2^{\mathrm{T}}$ grew well in R2A and SM broths, these two media were used for further analysis. Physiological and biochemical properties of strain BUZ $2^{\mathrm{T}}$ and the two reference strains were determined using API 20NE, API 20E, API 50CH and API ZYM strips (bioMérieux) according to the manufacturer's instructions. The API $50 \mathrm{CH}$ strips were inoculated with cells suspended in AUX medium (bioMérieux). API 20NE, API 20E and API 50CH strips were inspected after 3 and 7 days at $30{ }^{\circ} \mathrm{C}$, whereas the incubation time for API ZYM was $5 \mathrm{~h}$ at $37^{\circ} \mathrm{C}$. The temperature range and optimum temperature for growth were determined in $\mathrm{R} 2 \mathrm{~A}$ broth by growing the cultures at $4,10,15,20,30,37$ and $40{ }^{\circ} \mathrm{C}$. The $\mathrm{pH}$ range and optimum $\mathrm{pH}$ for growth were examined in SM broth adjusted to $\mathrm{pH}$ 5.0-11.0 (at $1 \mathrm{pH}$ unit intervals) using $\mathrm{KH}_{2} \mathrm{PO}_{4}$ and $\mathrm{K}_{2} \mathrm{HPO}_{4}$ prior to autoclaving. Higher $\mathrm{pH}$ was reached with additional $\mathrm{NaOH}$. The $\mathrm{pH}$ was verified after autoclaving with $\mathrm{pH}$ strips. Growth at different temperatures and $\mathrm{pH}$ was monitored for up to 1 week. Additionally, tolerance of $\mathrm{NaCl}$ was tested on $\mathrm{R} 2 \mathrm{~A}$ plates adjusted to $0-10 \% \mathrm{NaCl}$ (at $0.5 \%$ intervals). Anaerocult $\mathrm{C}$ (Merck) was used to generate an oxygendepleted $\left(5-7 \% \mathrm{O}_{2}\right)$ and carbon dioxide-enriched (8-10\% $\mathrm{CO}_{2}$ ) atmosphere in anaerobe jars. Growth was followed for up to 1 week. Hydrolysis of starch, xylan, CM-cellulose, pectin, amylopectin, agar and agarose was tested by adding $0.5 \%$ of the respective polysaccharide to nutrient medium (Tindall et al., 2007) gellified using gellan gum. A single streak of the test organism was made across the centre of each plate. After 3-5 days of incubation, the plates were

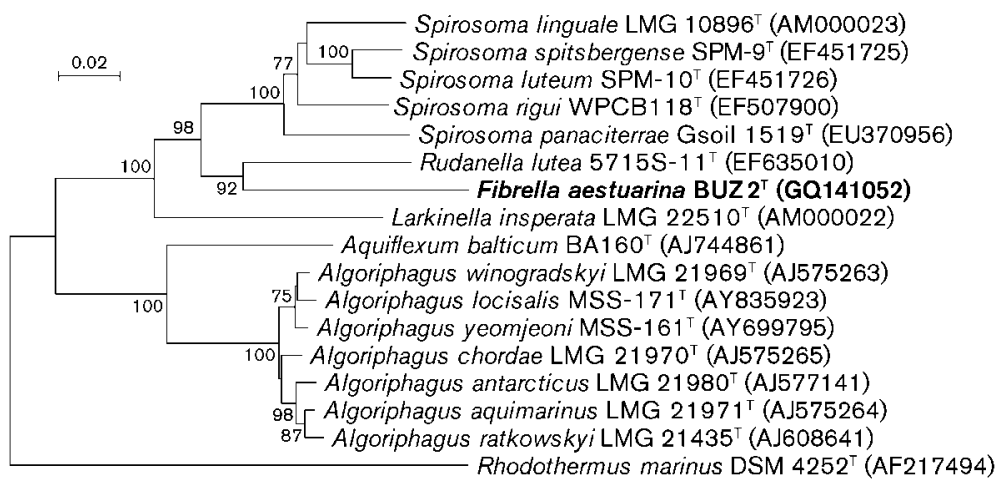

Fig. 1. Neighbour-joining phylogenetic tree based on 16S rRNA gene sequences showing the relationship of strain BUZ $2^{\top}$ with representative members of the family Cytophagaceae. Bootstrap values (expressed as percentages of 1000 replications) greater than $70 \%$ are shown at branch nodes. Bar, 0.02 substitutions per nucleotide position. Accession numbers are given in parentheses. The tree was rooted using Rhodothermus marinus DSM $4252^{\top}$ as the outgroup. 
Table 1. Phenotypic properties of strain BUZ $2^{\top}$ and its closest neighbours

Data were obtained in this study unless indicated. In API ZYM strips, all three strains were positive for alkaline phosphatase, esterase (C4), esterase lipase (C8), leucine arylamidase, valine arylamidase, cystine arylamidase, trypsin, acid phosphatase, naphthol-AS-BI-phosphohydrolase, $\beta$-glucosidase, $\alpha$-chymotrypsin and $N$-acetyl- $\beta$-glucosaminidase activities and negative for lipase (C14) and $\beta$-glucuronidase activities. None of the strains exhibited gliding motility. In API 20NE and API 20E strips, all strains were negative for indole and $\mathrm{H}_{2} \mathrm{~S}$ production, glucose fermentation, arginine dihydrolase, lysine decarboxylase, ornithine decarboxylase and urease activities, nitrate reduction, citrate utilization and assimilation of D-mannitol, capric acid, adipic acid, malic acid, trisodium citrate and phenylacetic acid; all strains were positive for aesculin hydrolysis and $\beta$-galactosidase activity. In API 50CH strips, all strains were negative for assimilation of glycerol, erythritol, D-arabinose, L-xylose, D-adonitol, L-sorbose, L-rhamnose, dulcitol, inositol, D-mannitol, D-sorbitol, xylitol, D-tagatose, D- and L-fucose, D- and L-arabitol and potassium 5-ketogluconate. All strains were positive for aesculin assimilation (API 50CH) and amylopectin hydrolysis. All strains were resistant to amikacin, colistin, gentamicin, kanamycin and polymyxin B and sensitive to amoxicillin, amoxicillin/clavulanic acid, chloramphenicol, ciprofloxacin, penicillin $\mathrm{G}$, rifampicin, streptomycin and tetracycline. + , Positive; w, weakly positive; -, negative.

\begin{tabular}{|c|c|c|c|}
\hline Characteristic & BUZ $2^{\mathrm{T}}$ & $\begin{array}{c}\text { R. lutea } \\
\text { DSM } 19387^{\mathrm{T}}\end{array}$ & $\begin{array}{l}\text { S. linguale } \\
\text { DSM } 74^{\mathrm{T}}\end{array}$ \\
\hline Cell morphology & $\begin{array}{l}\text { Rods, } \\
\text { filaments }\end{array}$ & $\begin{array}{l}\text { Rods, } \\
\text { filaments }\end{array}$ & $\begin{array}{c}\text { Ring-like, } \\
\text { horseshoe- } \\
\text { shaped }\end{array}$ \\
\hline Colony colour & Pink & Orange & Yellow \\
\hline Temperature range $\left({ }^{\circ} \mathrm{C}\right)$ & $10-40$ & $10-40$ & $4-37$ \\
\hline $\mathrm{pH}$ range (optimum) & $6-8(7)$ & $6-11(7)$ & $6-8(8)$ \\
\hline Tolerance of $\mathrm{NaCl}(\%)$ & $0-0.5$ & $0-2$ & $0-1.25$ \\
\hline Growth on peptone & - & $\mathrm{w}$ & - \\
\hline Oxidase activity & - & - & + \\
\hline \multicolumn{4}{|l|}{ Hydrolysis of: } \\
\hline Gelatin & + & - & - \\
\hline Starch & + & $\mathrm{W}$ & $\mathrm{w}$ \\
\hline CM-cellulose & + & - & - \\
\hline Agar & + & - & - \\
\hline Xylan & + & + & - \\
\hline Casein & + & + & - \\
\hline Agarose & + & - & - \\
\hline \multicolumn{4}{|l|}{$\begin{array}{l}\text { Assimilation of (API 20NE } \\
\text { and } 50 \mathrm{CH} \text { ): }\end{array}$} \\
\hline D-Glucose & + & - & + \\
\hline L-Arabinose & + & - & $\mathrm{w}$ \\
\hline D-Mannose & + & - & + \\
\hline $\mathrm{N}$-Acetylglucosamine & + & - & + \\
\hline Maltose & + & - & + \\
\hline D-Fructose & + & - & + \\
\hline Raffinose & + & - & + \\
\hline Potassium gluconate & $\mathrm{W}$ & - & - \\
\hline $\begin{array}{l}\text { Methyl } \beta \text {-D- } \\
\quad \text { xylopyranoside }\end{array}$ & + & - & - \\
\hline
\end{tabular}

Table 1. cont.

\begin{tabular}{|c|c|c|c|}
\hline Characteristic & $\operatorname{BUZ} 2^{T}$ & $\begin{array}{c}\text { R. lutea } \\
\text { DSM } 19387^{\mathrm{T}}\end{array}$ & $\begin{array}{l}\text { S. linguale } \\
\text { DSM } 74^{\mathrm{T}}\end{array}$ \\
\hline D-Lyxose & - & - & + \\
\hline Glycogen & + & - & - \\
\hline Arbutin & + & - & - \\
\hline D-Ribose & + & - & - \\
\hline D-Xylose & + & - & + \\
\hline D-Galactose & + & - & + \\
\hline $\begin{array}{l}\text { Methyl } \alpha \text {-D- } \\
\text { mannopyranoside }\end{array}$ & + & - & + \\
\hline $\begin{array}{l}\text { Methyl } \alpha \text {-D- } \\
\text { glucopyranoside }\end{array}$ & + & - & + \\
\hline Amygdalin & w & - & + \\
\hline Salicin & + & - & + \\
\hline Cellobiose & + & - & + \\
\hline Lactose & + & - & + \\
\hline Melibiose & + & - & + \\
\hline Sucrose & + & - & + \\
\hline Trehalose & + & - & + \\
\hline Inulin & + & - & + \\
\hline Melezitose & + & - & + \\
\hline Starch & + & - & + \\
\hline Gentiobiose & + & - & $\mathrm{w}$ \\
\hline Turanose & + & - & + \\
\hline $\begin{array}{l}\text { Potassium 2- } \\
\text { ketogluconate }\end{array}$ & w & - & - \\
\hline \multicolumn{4}{|l|}{$\begin{array}{l}\text { Enzyme activity (API } \\
\text { ZYM) }\end{array}$} \\
\hline$\alpha$-Fucosidase & + & - & - \\
\hline$\alpha$-Mannosidase & + & - & + \\
\hline$\alpha$-Glucosidase & + & - & + \\
\hline$\alpha$-Galactosidase & + & - & + \\
\hline$\beta$-Galactosidase & + & - & + \\
\hline $\begin{array}{l}\text { Susceptibility to } \\
\text { vancomycin }\end{array}$ & - & + & + \\
\hline $\begin{array}{l}\text { DNA G }+ \text { C content } \\
(\mathrm{mol} \%)\end{array}$ & 56.5 & $55^{a_{*}}$ & $51-53^{b}$ \\
\hline
\end{tabular}

${ }^{\star}$ Data taken from: $a$, Weon et al. (2008); $b$, Larkin \& Borrall (1984) (range of values for four strains).

flooded with iodine solution. A positive test result was indicated by a colourless area around the cell growth. Hydrolysis of casein was tested on milk agar prepared according to the Sigma recipe (15 g agar, $10 \mathrm{ml}$ fresh milk, $5 \mathrm{~g}$ peptone and $1 \mathrm{~g}$ yeast extract $\left.\mathrm{l}^{-1}\right)$. A hole was made in the centre of the milk agar and subsequently filled with cell suspension in $0.7 \% \mathrm{NaCl}$. The plates were inspected for clear zones around the hole after 2 and 5 days of incubation.

Susceptibility to antibiotics was tested using the discdiffusion method on R2A plates. The results were interpreted according to the guidelines set forth by the CLSI (2008). The following antibiotics (all from bioMérieux) were tested ( $\mu \mathrm{g}$ per disc unless indicated): amikacin (30), 
amoxicillin (10), amoxicillin/clavulanic acid (20/10), chloramphenicol (30), ciprofloxacin (5), colistin (30 U), gentamicin sulfate (10), kanamycin (30), penicillin G (10 U), polymyxin B (300 U), rifampicin (30), streptomycin (10), tetracycline (30) and vancomycin (30).

Strain BUZ $2^{\mathrm{T}}$ produced a pink pigment with absorbance peaks at 482 and $506 \mathrm{~nm}$, with the major peak at $482 \mathrm{~nm}$, whereas the major peak and shoulder of the closest relative, S. linguale DSM $74^{\mathrm{T}}$, were at 452 and $480 \mathrm{~nm}$, respectively. $R$. lutea DSM $19387^{\mathrm{T}}$ showed a major peak at $476 \mathrm{~nm}$ and shoulders at 452 and $506 \mathrm{~nm}$ (see Supplementary Fig. S1, available in IJSEM Online). Absorption between 380 and $550 \mathrm{~nm}$ probably results from the presence of carotenoid pigments (Zscheile et al., 1942).

The phenotypic characteristics of strain BUZ $2^{\mathrm{T}}$ are given in Table 1 and in the genus and species descriptions. In contrast to Finster et al. (2009), we did not observe gliding motility for S. linguale DSM $74^{\mathrm{T}}$.

For fatty acid analysis, strain BUZ $2^{\mathrm{T}}$, R. lutea DSM $19387^{\mathrm{T}}$ and S. linguale DSM $74^{\mathrm{T}}$ were grown in SM broth for 3 days at room temperature. Fatty acids were analysed by the Identification Service of the Deutsche Sammlung von Mikroorganismen und Zellkulturen (DSMZ, Braunschweig, Germany) according to the standard protocol of the MIDI/ Hewlett Packard Microbial Identification System (Sasser, 1990). Quinone and polar lipid analyses and determination of the DNA G + C content of strain BUZ $2^{\mathrm{T}}$ were also carried out by the DSMZ and Dr B. J. Tindall. The quinone content of $R$. lutea DSM $19387^{\mathrm{T}}$ was also determined in this study. Extraction and purification of genomic DNA of strain BUZ $2^{\mathrm{T}}$ was done following the protocol of Cashion et al. (1977) and the $\mathrm{G}+\mathrm{C}$ content was measured by HPLC (Mesbah et al., 1989).

The cellular fatty acid profiles of strain BUZ $2^{\mathrm{T}}, S$. linguale DSM $74^{\mathrm{T}}$ and R. lutea DSM $19387^{\mathrm{T}}$ are shown in Table 2 . The dominant fatty acids of strain BUZ $2^{\mathrm{T}}$ were summed feature 3 (comprising $\mathrm{C}_{16: 1} \omega 7 c$ and/or iso- $\mathrm{C}_{15: 0}$ $2-\mathrm{OH} ; 33.1 \%), \mathrm{C}_{16: 1} \omega 5 c(17.5 \%)$, iso- $\mathrm{C}_{15: 0}(11.9 \%)$, $\mathrm{C}_{16: 0}(9.8 \%)$ and iso- $\mathrm{C}_{17: 0} 3-\mathrm{OH}(9.3 \%)$. Although the overall fatty acid composition of the three strains was rather similar, strain BUZ $2^{\mathrm{T}}$ could be distinguished from its closest phylogenetic neighbours by a smaller proportion of summed feature 3 , a larger proportion of iso- $\mathrm{C}_{16: 0}$ and the presence of iso- $\mathrm{C}_{17: 0}$, iso- $\mathrm{C}_{17: 1} \omega 9 c$ and anteiso- $\mathrm{C}_{17: 0}$.

Menaquinone 7 (MK-7) was the only respiratory quinone found in strain BUZ $2^{\mathrm{T}}$, in agreement with previous observations for members of the genus Spirosoma. MK-7 was also the major respiratory quinone in $R$. lutea DSM $19387^{\mathrm{T}}$, but a small amount of MK-6 was also found.

The major polar lipid of strain BUZ $2^{\mathrm{T}}$ was phosphatidylethanolamine, but several unidentified aminolipids, phospholipids and aminophospholipids were also detected (Supplementary Fig. S2). Overall, this polar lipid profile was more similar to that of $S$. linguale DSM $74^{\mathrm{T}}$ than to
Table 2. Fatty acid content of strain BUZ $2^{\top}$ and its closest neighbours

Strains: 1 , BUZ $2^{\mathrm{T}} ; 2$, R. lutea DSM $19387^{\mathrm{T}} ; 3$, S. linguale DSM $74^{\mathrm{T}}$. Values are percentages of total fatty acids; components amounting to $<1 \%$ of the total fatty acids in all three strains are not shown. tr, Trace amounts $(<1 \%)$; ND, not detected. Data are from this study; bacteria were grown in SM broth at room temperature for 3 days.

\begin{tabular}{|c|c|c|c|}
\hline Fatty acid & 1 & 2 & 3 \\
\hline \multicolumn{4}{|l|}{ Straight-chain } \\
\hline $\mathrm{C}_{15: 0}$ & 1.0 & 1.1 & $\operatorname{tr}$ \\
\hline $\mathrm{C}_{16: 0}$ & 9.8 & 4.3 & 3.7 \\
\hline \multicolumn{4}{|l|}{ Branched saturated } \\
\hline iso- $\mathrm{C}_{13: 0}$ & $\mathrm{ND}$ & ND & 2.0 \\
\hline iso- $\mathrm{C}_{15: 0}$ & 11.9 & 8.3 & 7.9 \\
\hline iso- $\mathrm{C}_{16: 0}$ & 1.3 & 1.3 & $\operatorname{tr}$ \\
\hline iso- $\mathrm{C}_{17: 0}$ & 3.4 & $\operatorname{tr}$ & $\operatorname{tr}$ \\
\hline anteiso- $\mathrm{C}_{15: 0}$ & 2.1 & 1.8 & 2.0 \\
\hline anteiso- $\mathrm{C}_{17: 0}$ & 1.7 & $\operatorname{tr}$ & $\operatorname{tr}$ \\
\hline \multicolumn{4}{|l|}{ Hydroxy } \\
\hline iso- $\mathrm{C}_{15: 0} 3-\mathrm{OH}$ & 1.3 & 2.3 & 2.6 \\
\hline $\mathrm{C}_{16: 0} 3-\mathrm{OH}$ & 1.6 & 3.6 & 2.2 \\
\hline iso- $\mathrm{C}_{17: 0} 3-\mathrm{OH}$ & 9.3 & 6.8 & 7.5 \\
\hline \multicolumn{4}{|l|}{ Monounsaturated } \\
\hline $\mathrm{C}_{16: 1} \omega 5 c$ & 17.5 & 21.2 & 18.1 \\
\hline iso- $\mathrm{C}_{17: 1} \omega 9 c$ & 1.2 & $\operatorname{tr}$ & $\operatorname{tr}$ \\
\hline Summed feature $3^{\star}$ & 33.1 & 42.0 & 46.1 \\
\hline
\end{tabular}

${ }^{*}$ Summed features are groups of two or three fatty acids that could not be separated by GLC using the MIDI system. Summed feature 3 comprised $\mathrm{C}_{16: 1} \omega 7 c$ and/or iso- $\mathrm{C}_{15: 0} 2-\mathrm{OH}$.

that of R. lutea DSM $19387^{\mathrm{T}}$ (Weon et al., 2008), but strain BUZ $2^{\mathrm{T}}$ differed from these strains in the number of each type of polar lipid identified.

The DNA G + C content of strain BUZ $2^{\mathrm{T}}$ was $56.5 \mathrm{~mol} \%$, slightly higher than the values reported for the two reference strains (Weon et al., 2008; Larkin \& Borrall, 1984).

Based on our analyses, we propose that strain BUZ $2^{\mathrm{T}}$ represents a novel genus and species, for which the name Fibrella aestuarina gen. nov., sp. nov. is proposed. On the basis of the new data obtained in this study, an emended description of the genus Rudanella is also proposed.

\section{Description of Fibrella gen. nov.}

Fibrella (Fib.rel'la. L. fem. n. fibra a fibre or filament; L. dim. suff. -ella; N.L. fem. n. Fibrella a small fibre, referring to the ability of the type species to produce filaments).

Cells are facultatively anaerobic, Gram-staining-negative, non-motile rods that form multicellular filaments. Catalase-positive and oxidase-negative. Nitrate is not reduced. Flexirubin-type pigments are not produced. Predominant cellular fatty acids are summed feature 3 $\left(\mathrm{C}_{16: 1} \omega 7 c\right.$ and/or iso- $\left.\mathrm{C}_{15: 0} 2-\mathrm{OH}\right), \mathrm{C}_{16: 1} \omega 5 c$, iso- $\mathrm{C}_{15: 0}$, 
$\mathrm{C}_{16: 0}$ and iso- $\mathrm{C}_{17: 0} 3-\mathrm{OH}$. The major polar lipid is phosphatidylethanolamine; several unidentified aminolipids, phospholipids and aminophospholipids also occur. The only respiratory quinone is MK-7. The G $+\mathrm{C}$ content of the type strain of the type species is $56.5 \mathrm{~mol} \%$. Phylogenetically, the genus belongs to the family Cytophagaceae within the phylum Bacteroidetes. The type species is Fibrella aestuarina.

\section{Description of Fibrella aestuarina sp. nov.}

Fibrella aestuarina (aes.tu.a.ri'na. L. n. aestuarium a tidal marsh; N.L. fem. adj. aestuarina belonging to a marsh, referring to the location where the type strain was isolated).

The following properties are in addition to those given in the genus description. After 1 day of incubation in SM broth, cells are usually $0.8 \mu \mathrm{m}$ wide and 1.1-6.9 $\mu \mathrm{m}$ long, but multicellular filaments up to $245 \mu \mathrm{m}$ long also occur (Fig. 2). During the transient growth phase in liquid culture, multicellular filaments up to $400 \mu \mathrm{m}$ long may be formed. Colonies on R2A are pink, convex and circular with regular edges. Flagellar and gliding motility are absent. Growth occurs in R2A, SM, NB and $0.5 \%$ yeast water and on YT agar and TSA but not on blood agar or MacConkey agar, or in peptone water. Grows at $\mathrm{pH}$ 6.0-8.0, with an optimum at $\mathrm{pH}$ 7.0. The temperature range for growth is $10-40{ }^{\circ} \mathrm{C}$, with an optimum at $25-30{ }^{\circ} \mathrm{C}$. Does not require $\mathrm{NaCl}$ for growth but can tolerate $0.5 \%(\mathrm{w} / \mathrm{v}) \mathrm{NaCl}$. Agar, agarose, amylopectin, casein, CM-cellulose, starch and xylan are hydrolysed (showing clear haloes around the colonies). Pectin is not hydrolysed. In the API 20E strip, negative results are observed for arginine dihydrolase, lysine decarboxylase, ornithine decarboxylase and urease activities, citrate utilization and $\mathrm{H}_{2} \mathrm{~S}$ and indole production. In the API ZYM strip, trypsin, $\alpha$-chymotrypsin, $\alpha$-galactosidase, $\beta$-galactosidase, $\alpha$-glucosidase, alkaline phosphatase, esterase (C4), esterase lipase (C8), leucine arylamidase, valine arylamidase, cystine arylamidase, acid phosphatase, naphthol-AS-BI-phosphohydrolase, $\beta$-glucosidase, $N$-acetyl- $\beta$-glucosaminidase, $\alpha$-mannosidase and $\alpha$-fucosidase activities are present; lipase (C14) and $\beta$-glucuronidase activities are absent. In the API $20 \mathrm{NE}$ strip, positive reactions are observed for $\beta$-galactosidase activity, aesculin and gelatin hydrolysis and assimilation of arabinose, glucose, maltose, mannose and $\mathrm{N}$-acetylglucosamine; potassium gluconate is weakly assimilated and negative reactions are observed for nitrate reduction, indole production, glucose fermentation, arginine dihydrolase and urease activities and assimilation of D-mannitol, capric acid, adipic acid, malic acid, trisodium citrate and phenylacetic acid. In the API $50 \mathrm{CH}$ strip after 7 days of incubation, the following substrates are assimilated: L-arabinose, D-ribose, $\mathrm{D}$-xylose, methyl $\beta$-D-xylopyranoside, D-galactose, D-glucose, D-fructose, D-mannose, methyl $\alpha$-D-mannopyranoside, methyl $\alpha$-D-glucopyranoside, $N$-acetylglucosamine, amygdalin, arbutin, aesculin, salicin, cellobiose, maltose, lactose (bovine origin), melibiose, sucrose, trehalose, inulin, melezitose, raffinose, starch, glycogen, gentiobiose, turanose and potassium 2-ketogluconate; potassium gluconate is weakly assimilated and the following substrates are not assimilated: glycerol, erythritol, D-arabinose, L-xylose, D-adonitol, L-sorbose, L-rhamnose, dulcitol, inositol, D-mannitol, D-sorbitol, xylitol, D-lyxose, D-tagatose, D- and L-fucose, D- and L-arabitol and potassium 5-ketogluconate. Resistant to amikacin $(30 \mu \mathrm{g})$, colistin $(30 \mathrm{U})$, gentamicin $(10 \mu \mathrm{g})$, kanamycin $(30 \mu \mathrm{g})$, polymyxin $\mathrm{B}(300 \mathrm{U})$ and vancomycin $(10 \mu \mathrm{g})$. Sensitive to amoxicillin $(10 \mu \mathrm{g})$, amoxicillin/clavulanic acid $(20 / 10 \mu \mathrm{g})$, chloramphenicol $(30 \mu \mathrm{g})$, ciprofloxacin $(5 \mu \mathrm{g})$, penicillin $\mathrm{G}(10 \mathrm{U})$, rifampicin $(30 \mu \mathrm{g})$, streptomycin $(30 \mu \mathrm{g})$ and tetracycline $(30 \mu \mathrm{g})$.

The type strain, BUZ $2^{\mathrm{T}}\left(=\right.$ CCUG $58136^{\mathrm{T}}=$ DSM $\left.22563^{\mathrm{T}}\right)$, was isolated from mud from a tidal flat on the North Sea coast of Germany.

\section{Emended description of the genus Rudanella Weon et al. 2008}

The description is as given by Weon et al. (2008) with the following emendation. The major respiratory quinone is MK-7, but a small amount of MK-6 is also detected. The antibiotic sensitivity profile of the type species is the same
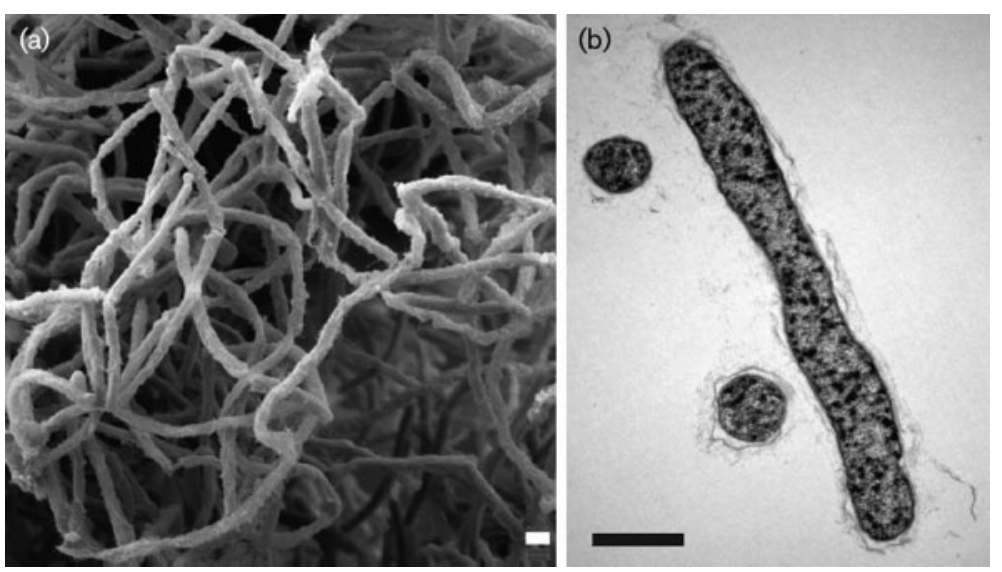

Fig. 2. Electron micrographs of strain BUZ $2^{\top}$. (a) Scanning electron micrograph showing filamentous cells. (b) Transmission electron micrograph of a longitudinal section and crosssections of bacterial cells. Bars, $1 \mu \mathrm{m}$. 
as that of Fibrella aestuarina, with the exception that Rudanella lutea is sensitive to vancomycin. The genus is a member of the family Cytophagaceae, phylum Bacteroidetes.

\section{Acknowledgements}

This work was supported by the Faculty of Science of the University of Zurich. We thank K. Finster, C. N. Seong, W.-T. Im and S.-W. Kwon for kindly providing submitted papers on the characterization of Spirosoma spitsbergense, S. luteum, S. panaciterrae, S. rigui and Rudanella lutea, M. Laturnus for help during sampling, G. Barmettler and K. Marquardt for performing electron microscopy and M. Eisenring for help during phenotypic tests. We thank the editor for extensive comments, in addition to two anonymous reviewers who helped to improve the manuscript.

\section{References}

Baik, K. S., Kim, M. S., Park, S. C., Lee, D. W., Lee, S. D., Ka, J.-O., Choi, S. K. \& Seong, C. N. (2007). Spirosoma rigui sp. nov., isolated from fresh water. Int J Syst Evol Microbiol 57, 2870-2873.

Bernardet, J.-F., Nakagawa, Y. \& Holmes, B. (2002). Proposed minimal standards for describing new taxa of the family Flavobacteriaceae and emended description of the family. Int J Syst Evol Microbiol 52, 1049-1070.

Cashion, P., Holder-Franklin, M. A., McCully, J. \& Franklin, M. (1977). A rapid method for the base ratio determination of bacterial DNA. Anal Biochem 81, 461-466.

CLSI (2008). Performance standards for antimicrobial susceptibility testing; 18th informational supplement. M100-S18. Wayne, PA: Clinical and Laboratory Standards Institute.

Finster, K. W., Herbert, R. A. \& Lomstein, B. A. (2009). Spirosoma spitsbergense sp. nov. and Spirosoma luteum sp. nov., isolated from a high Arctic permafrost soil, and emended description of the genus Spirosoma. Int J Syst Evol Microbiol 59, 839-844.

Flint, K. P. (1985). A note on a selective agar medium for the enumeration of Flavobacterium species in water. J Appl Bacteriol 59, 561-566.

Gosink, J. J., Woese, C. R. \& Staley, J. T. (1998). Polaribacter gen. nov., with three new species, $P$. irgensii sp. nov., $P$. franzmannii sp. nov. and $P$. filamentus sp. nov., gas vacuolated polar marine bacteria of the Cytophaga-Flavobacterium-Bacteroidetes group and reclassification of 'Flectobacillus glomeratus' as Polaribacter glomeratus comb. nov. Int J Syst Bacteriol 48, 223-235.

Kulichevskaya, I. S., Zaichikova, M. V., Detkova, E. N., Dedysh, S. N. \& Zavarzin, G. A. (2009). Larkinella arboricola sp. nov., a new spiralshaped bacterium of the phylum Bacteroidetes isolated from the microbial community of decomposing wood. Mikrobiologiia 78, 741746 (in Russian).

Kumar, S., Tamura, K., Jakobsen, I. B. \& Nei, M. (2001). MEGA2: molecular evolutionary genetics analysis software. Bioinformatics 17, $1244-1245$.

Larkin, J. M. \& Borrall, R. (1984). Family I. Spirosomaceae Larkin and Borrall 1978, 595 ${ }^{\mathrm{AL}}$. In Bergey's Manual of Systematic Bacteriology, vol. 1, pp. 125-126. Edited by N. R. Krieg \& J. G. Holt. Baltimore: Williams \& Wilkins.

Larkin, J. M. \& Williams, P. M. (1978). Runella slithyformis gen. nov., sp. nov. a curved, nonflexible, pink bacterium. Int J Syst Bacteriol 28, 32-36.
Larkin, J. M., Williams, P. M. \& Taylor, R. (1977). Taxonomy of the genus Microcyclus Ørskov 1928: reintroduction and emendation of the genus Spirosoma Migula 1894 and proposal of a new genus, Flectobacillus. Int J Syst Bacteriol 27, 147-156.

Ludwig, W., Strunk, O., Klugbauer, N., Weizenegger, M., Neumaier, J., Bachleitner, M. \& Schleifer, K. H. (1998). Bacterial phylogeny based on comparative sequence analysis. Electrophoresis 19, 554-568.

Ludwig, W., Euzéby, J. \& Whitman, W. B. (2008). Draft taxonomic outline of the Bacteroidetes, Planctomycetes, Chlamydiae, Spirochaetes, Fibrobacteres, Fusobacteria, Acidobacteria, Verrucomicrobia, Dictyoglomi, and Gemmatimonadetes. http://www.bergeys.org/outlines/Bergeys_Vol_ 4_Outline.pdf

Mesbah, M., Premachandran, U. \& Whitman, W. B. (1989). Precise measurement of the $\mathrm{G}+\mathrm{C}$ content of deoxyribonucleic acid by highperformance liquid chromatography. Int J Syst Bacteriol 39, 159167.

Reasoner, D. J. \& Geldreich, E. E. (1985). A new medium for the enumeration and subculture of bacteria from potable water. Appl Environ Microbiol 49, 1-7.

Reichenbach, H. (1992). The order Cytophagales. In The Prokaryotes. A Handbook of the Biology of Bacteria: Ecophysiology, Isolation, Identification, Applications, 2nd edn, pp. 3631-3675. Edited by A. Balows, H. G. Trüper, M. Dworkin, W. Harder \& K. H. Schleifer. New York: Springer.

Sasser, M. (1990). Identification of bacteria by gas chromatography of cellular fatty acids, Technical Note 101. Newark, DE: MIDI, Inc.

Svercel, M., Christen, D., Moenne-Loccoz, Y., Duffy, B. \& Defago, G. (2009). Effect of long-term vineyard monoculture on rhizosphere populations of pseudomonads carrying the antimicrobial biosynthetic genes phlD and/or honAB. FEMS Microbiol Ecol 68, 25-36.

Ten, L. N., Xu, J.-L., Jin, F.-X., Im, W.-T., Oh, H.-M. \& Lee, S.-T. (2009). Spirosoma panaciterrae sp. nov., isolated from soil. Int J Syst Evol Microbiol 59, 331-335.

Thompson, J. D., Gibson, T. J., Plewniak, F., Jeanmougin, F. \& Higgins, D. G. (1997). The CLUSTAL_X windows interface: flexible strategies for multiple sequence alignment aided by quality analysis tools. Nucleic Acids Res 25, 4876-4882.

Tindall, B. J., Sikorski, J., Smibert, R. A. \& Krieg, N. R. (2007). Phenotypic characterization and the principles of comparative systematics. In Methods for General and Molecular Microbiology, 3rd edn, pp. 330-393. Edited by T. J. Beveridge, J. A. Breznak, G. A. Marzluf, T. M. Schmidt \& L. R. Snyder. Washington, DC: American Society for Microbiology.

Vancanneyt, M., Nedashkovskaya, O. I., Snauwaert, C., Mortier, S., Vandemeulebroecke, K., Hoste, B., Dawyndt, O., Frolova, G. M., Janssens, D. \& Swings, J. (2006). Larkinella insperata gen. nov., sp. nov., a bacterium of the phylum 'Bacteroidetes' isolated from water of a steam generator. Int J Syst Evol Microbiol 56, 237-241.

Weon, H.-Y., Noh, H.-J., Son, J.-A., Jang, H. B., Kim, B.-Y., Kwon, S.-W. \& Stackebrandt, E. (2008). Rudanella lutea gen. nov., sp. nov., isolated from an air sample in Korea. Int J Syst Evol Microbiol 58, 474-478.

Zscheile, F. P., White, J. W., Beadle, B. W. \& Roach, J. R. (1942). The preparation and absorption spectra of five pure carotenoid pigments. Plant Physiol 17, 331-346.

Zwickl, D. J. (2006). Genetic algorithm approaches for the phylogenetic analysis of large biological sequence datasets under the maximum likelihood criterion. $\mathrm{PhD}$ dissertation, University of Texas at Austin, Austin, TX, USA. 